\title{
Vascular-induced compensatory pseudo-retrocollis
}

Figure 1 Pseudo-retrocollis
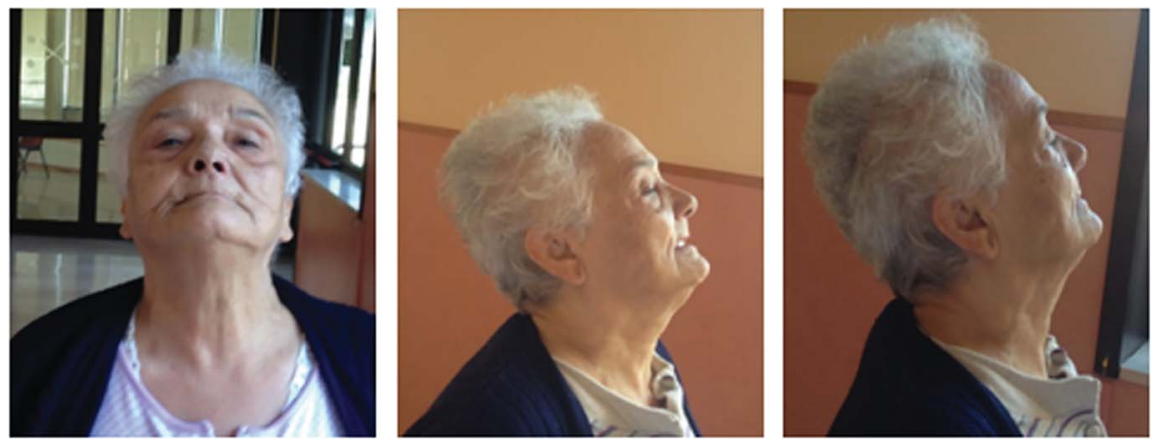

Compensatory neck posture to visual loss.

A 75-year-old woman presented with a sudden onset of blurred vision and abnormal neck posture. Neurologic examination showed pseudo-retrocollis (RC) (figure 1), reduced by closing her eyes, and a right side visual field defect. CT scan showed a left temporo-occipital ischemic lesion and visual field campimetry revealed right superior homonymous quadrantanopia (sHQ) (figure 2, A and B).

\section{Figure 2 Diagnostic workup}

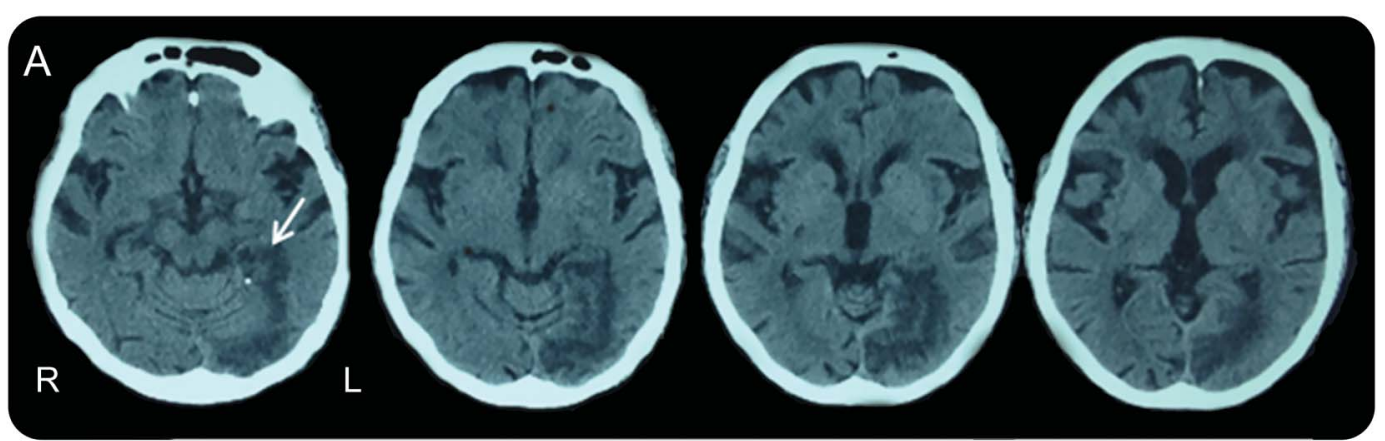

B
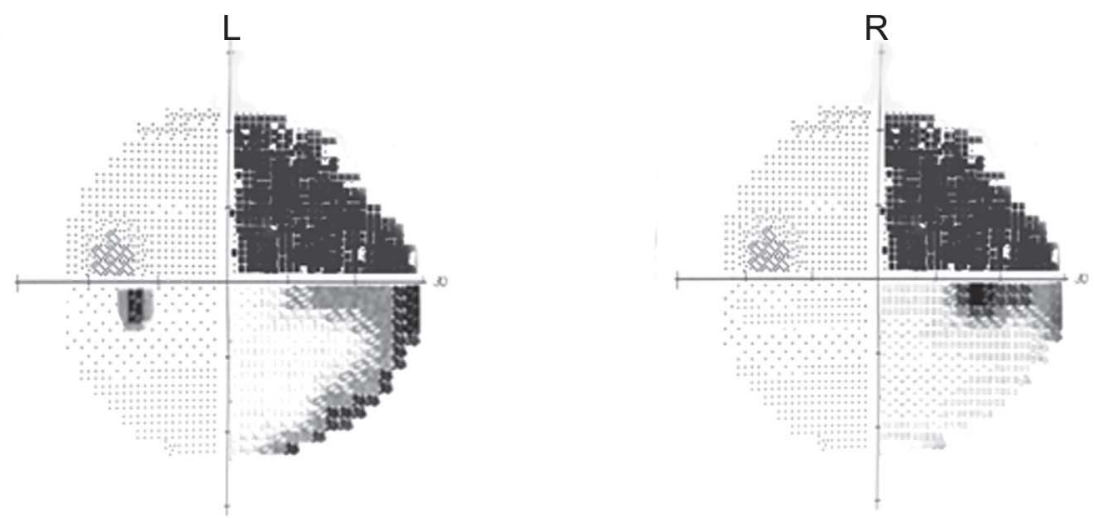

(A) Brain CT: left temporo-occipital hypondensity involves the Meyer loop (arrow). (B) Visual field campimetry: loss of the right upper quadrant from each visual field. 
$\mathrm{RC}$ is a cervical dystonia observed in both neurologic and non-neurologic diseases. ${ }^{1}$ An acute compensatory neck posture, resembling RC, could be seen in patients with sHQ due to a disruption of Meyer loop ${ }^{2}$ when they try to bring up the remaining inferior side vision to the horizon.

Alfonso Giordano, MD, PhD, Gioacchino Tedeschi, $M D$, PhD, Alessandro Tessitore, MD, PhD

From the Second University of Naples (A.G., G.T., A.T.) and the Institute for Diagnosis and Care "Hermitage Capodimonte" (A.G.), Naples, Italy.

Author contributions: Dr. Alfonso Giordano drafted the manuscript. Prof. Alessandro Tessitore and Prof. Gioacchino Tedeschi revised the manuscript.

Study funding: No targeted funding reported.

Disclosure: The authors report no disclosures relevant to the manuscript. Go to Neurology.org for full disclosures.

Correspondence to Dr. Tessitore: alessandro.tessitore@unina2.it

1. Albanese A, Bhatia K, Bressman SB, et al. Phenomenology and classification of dystonia: a consensus update. Mov Disord 2013; 28:863-873.

2. Powell HW, Parker GJ, Alexander DC, et al. MR tractography predicts visual field defects following temporal lobe resection. Neurology 2005;65:596-599.

\section{Get Connected. Stay Connected.}

Connect with the American Academy of Neurology's popular social media channels to stay up-todate on the latest news and breakthroughs in neurology, and network with peers and neurology thought leaders. Visit AAN.com/Connect.

\section{Visit the Neurology ${ }^{\circledR}$ Web Site at Neurology.org}

- Enhanced navigation format

- Increased search capability

- Highlighted articles

- Detailed podcast descriptions

- RSS Feeds of current issue and podcasts

- Personal folders for articles and searches

- Mobile device download link

- AAN Web page links

- Links to Neurology Now ${ }^{\circledR}$, Neurology Today ${ }^{\circledR}$, and Continuum ${ }^{\circledR}$

- Resident \& Fellow subsite

(1) Find Neurology ${ }^{\circledR}$ on Facebook: http://tinyurl.com/neurologyfan

twitter Follow Neurology ${ }^{\circledR}$ on Twitter: https://twitter.com/GreenJournal 


\title{
Neurology
}

\author{
Vascular-induced compensatory pseudo-retrocollis \\ Alfonso Giordano, Gioacchino Tedeschi and Alessandro Tessitore \\ Neurology 2015;84;2005-2006 \\ DOI 10.1212/WNL.0000000000001568
}

This information is current as of May 11, 2015

$\begin{array}{ll}\begin{array}{l}\text { Updated Information \& } \\ \text { Services }\end{array} & \begin{array}{l}\text { including high resolution figures, can be found at: } \\ \text { http://n.neurology.org/content/84/19/2005.full }\end{array} \\ \text { References } & \text { This article cites } 2 \text { articles, } 1 \text { of which you can access for free at: } \\ & \text { http://n.neurology.org/content/84/19/2005.full\#ref-list-1 } \\ \text { Subspecialty Collections } & \text { This article, along with others on similar topics, appears in the } \\ & \text { following collection(s): } \\ & \text { All Cerebrovascular disease/Stroke } \\ & \text { http://n.neurology.org/cgi/collection/all_cerebrovascular_disease_strok } \\ & \text { e } \\ & \text { Dystonia } \\ & \text { http://n.neurology.org/cgi/collection/dystonia } \\ & \text { Visual fields } \\ & \text { http://n.neurology.org/cgi/collection/visual_fields } \\ & \text { Visual loss } \\ \text { http://n.neurology.org/cgi/collection/visual_loss } & \\ & \text { Information about reproducing this article in parts (figures,tables) or in } \\ & \text { its entirety can be found online at: } \\ \text { http://www.neurology.org/about/about_the_journal\#permissions } \\ \text { Information about ordering reprints can be found online: } \\ \text { hermissions \& Licensing } \\ \text { http://n.neurology.org/subscribers/advertise }\end{array}$

Neurology ${ }^{\circledR}$ is the official journal of the American Academy of Neurology. Published continuously since 1951, it is now a weekly with 48 issues per year. Copyright (C 2015 American Academy of Neurology. All rights reserved. Print ISSN: 0028-3878. Online ISSN: 1526-632X.

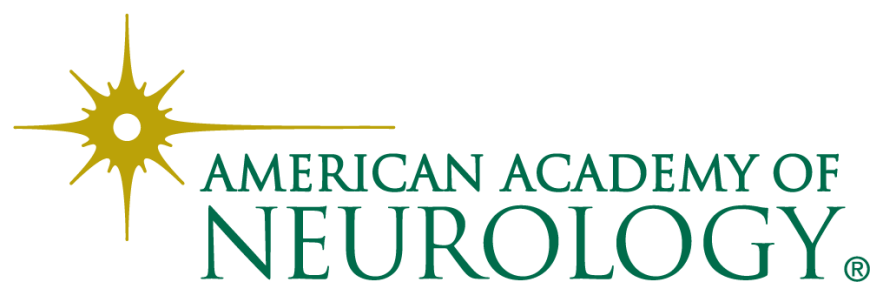

